\title{
Hubungan Karakteristik Individu dan Faktor Lingkungan dengan Asupan Serat Makanan Mahasiswa Politeknik Negeri Jember
}

\author{
Rifkatul Mabruroh ${ }^{1}$, Dahlia Indah Amareta ${ }^{1}$ \\ Jurusan Kesehatan Politeknik Negeri Jember, Indonesia ${ }^{I}$ \\ e-mail:rifka.m96@gmail.com
}

\begin{abstract}
Dietary fiber is a non-nutritious substance that is useful for diet. Fiber is a group of carbohydrates that have a very complex chemical structure and derived from plant parts that can be consumed and has properties of resistance to the digestive process and absorption of the small intestine with complete or parsial fermentation of the large intestine. The purpose of this research is to know the correlation of individual characteristic (knowledge, gender) and environmental factor (peer role, residence) with food fiber intake Student of State Polytechnic Jember. The type of this research is analytic survey with cross sectional study design, sampling using stratified random sampling. Data collection was conducted from November to December 2017 at Jember State Polytechnic, using questionnaire, food food record form for 3 days (2 days active and 1 day off) to know food fiber intake and involving 95 respondents. Data analysis used univariate analysis (frequency distribution), bivariate analysis (chi-square test). The results showed that there was a relationship between knowledge with food fiber intake 0,002 $(p<0,05)$, there was relationship between gender with food fiber intake $0,003(p<0,05)$, there was relationship between peer role with food fiber intake $0,001(p<0.05)$, there was a relationship between dwelling and dietary fiber intake of $0,000(p<0.05)$. Conclusion There is a correlation of knowledge, gender, role of peers, residence with intake of dietary fiber.
\end{abstract}

Keywords: environmental factors, fiber intake, individual characteristics

\section{Pendahuluan}

Perkembangan teknologi dalam berbagai bidang telah membawa ke era globalisasi di bidang pangan dan gizi. Salah satu dampak dari globalisasi di bidang pangan dan gizi adalah terjadinya pergeseran pola makan (Santoso, 2011).

Pola makan yang baik yaitu mencakup semua kebutuhan zat gizi maupun zat non gizi termasuk serat yang terkandung dalam makanan. Pola makan yang salah seperti kurangnya asupan serat dapat menyebabkan berbagai jenis penyakit, contohnya penyakit degeneratif seperti obesitas dan jantung koroner (Sunarti, 2017).

Hasil Riskesdas tahun 2013 mengenai konsumsi buah dan sayur di Indonesia masih sangat kurang, padahal sayur dan buah merupakan penyumbang serat yang baik dan sangat dianjurkan. Data Riskesdas 2013, prevalensi konsumsi buah dan sayur yang kurang di Indonesia sebesar 93,5\% (Kemenkes, 2013). Studi pendahuluan yang dilakukan peneliti di Politeknik Negeri Jember diketahui rata-rata asupan serat makanan mahasiswa tergolong rendah yaitu 8,44 gram/hari.
Pengetahuan gizi merupakan kemampuan untuk menerapkan informasi tentang kebutuhan pangan dan nilai pangan dalam kehidupan sehari-hari. Pengetahuan sangat berhubungan dengan pemilihan makanan, khusunya dalam memilih makanan yang tepat (Notoatmodjo, 2007). Faktor lain yang berhubungan dengan asupan serat yaitu jenis kelamin. Perempuan lebih mementingkan penampilan fisiknya dibandingkan dengan laki-laki (Soetjiningsih, 2010). Asupan serat juga berhubungan dengan peran teman sebaya, dalam pemilihan makanan tidak lagi didasarkan pada kandungan gizi tetapi sekedar bersosialisasi untuk kesenangan dan supaya tidak kehilangan status sosial (Khomsan, 2010). Tempat tinggal juga menjadi penyebab rendahnya asupan serat seseorang, karena dapat memudahkan dalam memperoleh makanan, menentukan banyak sedikitnya makanan yang didapat untuk dikonsumsi (Suhardjo, 2007). Tujuan dari penelitian ini adalah mengetahui hubungan karakteristik individu (pengetahuan dan jenis kelamin) dan faktor lingkungan (peran teman sebaya dan tempat tinggal) dengan asupan serat makanan pada mahasiswa Politeknik Negeri Jember. 


\section{Metode}

Jenis penelitian ini adalah Survei Analitik dengan desain penelitian Cross Sectional.

\subsection{Metode Pengumpulan Data}

Populasi penelitian ini adalah seluruh Mahasiswa aktif Politeknik Negeri Jember dengan jumlah populasi 6.943 mahasiswa dari semua jurusan. Subjek dalam penelitian ini 95 subjek yang memenuhi kriteria inklusi dan eksklusi. Kriteria inklusi mahasiswa aktif, tidak dalam keadaan atau melakukan diet. Kriteria eksklus tidak mengumpulkan instrumen, sakit, tidak bersedia menjadi responden. Pengambilan subjek menggunakan teknik Cluster Random Sampling.

Variabel dalam penelitian ini adalah variabel Independen (bebas), yaitu karakteristik individu (jenis kelamin, pengetahuan serat makanan) dan faktor lingkungan (teman sebaya, tempat tinggal), variabel Dependen (terikat), yaitu asupan serat makanan.

Instrumen dalam penelitian ini adalah form food record, nutri survey, food model, angket pengetahuan serat makanan dan peran teman sebaya. Pemberian skor setiap jawaban yang diharapkan diberi skor satu (1) dan setiap jawaban yang tidak diharapkan diberi skor nol (0).

Penelitian ini dilakukan di Politeknik Negeri Jember pada bulan Februari 2017 sampai Mei 2018 dengan proses pengumpulan data November sampai Desember 2017

Data primer merupakan data yang diperoleh langsung dari responden meliputi, data identitas responden (nama, jenis kelamin, usia), tempat tinggal, pengetahuan mengenai serat makanan dan peran teman sebaya yang didapat dari angket, data asupan serat makanan menggunakan form record selama 3 hari berturut-turut ( 2 hari aktif dan 1 hari libur).Data sekunder merupakan data yang didapatkan, dimana data tersebut umumnya telah diolah oleh pihak tertentu. Data yang didapatkan meliputi data jumlah Mahasiswa aktif Politeknik Negeri Jember.

Uji coba instrumen dalam penelitian ini dilakukan pada 20 mahasiswa Politeknik
Negeri Jember yang tidak menjadi subjek. Analisis validitas dengan menggunakan rumus korelasi product moment. Angket yang diuji terdiri dari angket pengetahuan serat makanan dan peran teman sebaya. Uji ini menggunakan IBM SPSS statistics versi 22 . Uji coba angket pengetahuan dengan 22 pernyataan didapatkan 19 pernyataan yang valid dan angket peran teman sebaya dengan 17 pernyataan didapatkan 14 pernyataan yang.

Uji reliabilitas dari masing-masing faktor dengan menggunakan uji AlphaCronbach. Pada uji angket penelitian ini didapatkan hasil reliabilitas sebesar 0,960 untuk angket pengetahuan dan angket peran teman sebaya hasil reliabilitasnya sebesar 0,928 .

\subsection{Metode Analisis Data}

Analisis uji menggunakan statistik Chi-Square atau alternatifnya (jika syarat uji Chi-Square tidak terpenuhi) dengan tingkat kepercayaan sebesar 95\%. Di dalam penelitian ini, untuk memudahkan dalam mengolah data peneliti menggunakan program IBM SPSS statistics versi 22 dengan $\mathrm{p}<0,05$. 


\section{Hasil dan Pembahasan}

Tabel 1. Analisis Hubungan Karakteristik Individu (Pengetahuan dan Jenis Kelamin) dan Faktor Lingkungan (Peran Teman Sebaya dan Tempat Tinggal) dengan Asupan Serat Makanan Mahasiswa Politeknik Negeri Jember

\begin{tabular}{|c|c|c|c|c|c|c|c|c|c|}
\hline \multirow[t]{3}{*}{ Variabel } & \multicolumn{6}{|c|}{ Asupan Serat Makanan } & \multirow{2}{*}{\multicolumn{2}{|c|}{ Total }} & \multirow[t]{3}{*}{$p$} \\
\hline & \multicolumn{2}{|c|}{$\begin{array}{l}\text { Sangat } \\
\text { kurang }\end{array}$} & \multicolumn{2}{|c|}{ Kurang } & \multicolumn{2}{|c|}{ Cukup } & & & \\
\hline & $\mathbf{n}$ & $\%$ & $\mathbf{n}$ & $\%$ & $\mathbf{n}$ & $\%$ & $\mathbf{n}$ & $\%$ & \\
\hline \multicolumn{10}{|l|}{ Pengetahuan } \\
\hline Kurang & 27 & 81,8 & 3 & 9,1 & 3 & 9,1 & 33 & 100 & \\
\hline Cukup & 24 & 75 & 2 & 6,25 & 6 & 18,75 & 32 & 100 & $0,002 *$ \\
\hline Baik & 12 & 40 & 11 & 36,7 & 7 & 23,3 & 30 & 100 & \\
\hline \multicolumn{10}{|l|}{ Jenis kelamin } \\
\hline Perempuan & 41 & 82 & 4 & 8 & 5 & 10 & 50 & 100 & $0,003 *$ \\
\hline Laki-laki & 22 & 48,9 & 12 & 26,7 & 11 & 24,4 & 45 & 100 & \\
\hline \multicolumn{10}{|c|}{ Peran teman sebaya } \\
\hline Tidak berperan & 30 & 85,7 & 2 & 5,7 & 3 & 8,6 & 35 & 100 & \\
\hline Kurang berperan & 21 & 70 & 3 & 10 & 6 & 20 & 30 & 100 & $0,001^{*}$ \\
\hline Berperan & 12 & 40 & 11 & 36,7 & 7 & 23,3 & 30 & 100 & \\
\hline \multicolumn{10}{|l|}{ Tempat tinggal } \\
\hline Kost & 45 & 80,4 & 3 & 5,4 & 8 & 14,2 & 56 & 100 & $0,000^{*}$ \\
\hline Rumah sendiri & 18 & 46,2 & 13 & 33,3 & 8 & 20,5 & 39 & 100 & \\
\hline
\end{tabular}

Keterangan : *Bermakna $(\mathrm{p}<0,05)$, uji chi-square.

Hasil analisis univariat tentang pengetahuan, rata-rata pengetahuan subjek tergolong kurang. Dari pengumpulan data yang dilakukan terdapat 6 pernyataan terbanyak yang jawaban dari responden tidak sesuai dengan yang diharapkan. Pernyataan tersebut diantaranya konsumsi serat dapat menaikkan berat badan, umbi-umbian bukan salah satu sumber serat, mencegah wasir kanker kolon bukan merupakan fungsi serat, konsumsi serat yang cukup dapat mengurangi risiko stroke, serat dapat mengontrol kadar glukosa dalam darah sehingga baik untuk penderita diabetes, dan konsumsi serat yang cukup dapat menghasilkan feses yang lembut dan tidak keras. Instrumen yang digunakan untuk mengetahui besarnya pengetahuan tentang serat makanan yaitu angket sehingga informasi yang didapatkan terbatas atau kurang mendalam.

Hasil penelitian menunjukkan sebagian besar responden berjenis kelamin perempuan dan sebagian kecil berjenis kelamin laki-laki. Banyaknya subjek perempuan dikarenakan sebagian besar subjek berasal dari jurusan kesehatan, dimana rata-rata mahasiswa jurusan kesehatan berjenis kelamin perempuan.
Hasil penelitian menunjukkan sebagian besar subjek dengan teman sebaya tidak berperan, hal tersebut dapat dikarenakan subjek dalam penelitian sibuk dalam mengerjakan tugas praktikum. Politeknik merupakan perguruan tinggi yang menyelenggarakan pendidikan vokasional, yaitu program pendidikan yang mengarah proses belajar mengajar pada tingkat keahlian, keterampilan sehingga jadwal kuliah selain teori juga disertakan dengan praktikum.

Dari pengumpulan data yang dilakukan terdapat peran teman sebaya yang jarang dilakukan dintaranya subjek tidak selalu bersama teman ketika membeli makanan, subjek pernah menolak ajakan teman sebaya untuk memilih makanan tertentu, teman sebaya tidak menganjurkan untuk mengonsumsi sayur dan buah, subjek dan teman sebaya jarang makan bersama, ketika sedang makan bersama, teman sebaya tidak menentukan jenis makanan yang dibeli, jika teman sebaya mengonsumsi/membeli buah subjek tidak ikut mengonsumsi/membeli, jika teman sebaya mengonsumsi/membeli sayur subjek tidak ikut mengonsumsi/membeli, teman sebaya tidak pernah memberikan informasi tentang 
makanan yang mengandung serat, teman sebaya menghiraukan apa yang dikonsumsi oleh subjek, dan teman sebaya tidak pernah mengingatkan tentang pentingnya mengonsumsi makanan tinggi serat.

Peran teman sebaya yang terbanyak dilakukan diantaranya subjek sering diajak makan di luar, ketika bersama teman sebaya pernah mengonsumsi sayur, ketika bersama teman sebaya pernah mengonsumsi buah, dan subjek sering pergi bersama teman sebaya untuk mengonsumsi makanan cepat saji. Instrumen yang digunakan untuk mengetahui besarnya peran teman sebaya terhadap asupan serat makanan yaitu angket sehingga informasi yang didapatkan terbatas atau kurang mendalam.

Selain pengaruh teman sebaya dari hasil penelitian yang dilakukan subjek bertempat tinggal di kost maupun rumah sendiri sering melihat/mencari informasi mengenai jenis makanan melalui media sosial seperti instagram. Sebagian besar subjek memilih makanan bukan berdasarkan kandungan gizi, akan tetapi berdasarkan makanan yang populer atau banyak diminati pada saat itu.

Hasil penelitian menunjukkan sebagian besar responden bertempat tinggal di kost dan sebagian kecil bertempat tinggal di rumah sendiri. Lebih banyaknya subjek yang bertempat tinggal di kost dikarenakan sebagian besar berasal dari luar Jember.

Hasil asupan serat makanan yang didapatkan dari hasil food record selama 3 hari yaitu 2 hari aktif dan 1 hari libur menunjukan asupan serat makanan terbanyak dalam kategori sangat kurang yaitu 10,72 gram/hari. Asupan sayur dan buah dari subjek rata-rata tidak sesuai dengan yang dianjurkan, padahal sayur dan buah merupakan sumber serat yang baik dan sangat dianjurkan. Sebagian besar subjek hanya mengonsumsi 1 porsi sayur dan jarang mengonsumsi buah. Adapun subjek mengonsumsi buah dalam bentuk jus, akan tetapi tidak setiap hari. Anjuran konsumsi sayur 3-4 porsi dalam sehari dan buah 2-3 porsi dalam sehari (Kemenkes, 2014).

Dari tabel 2 dapat diketahui bahwa subjek dengan pengetahuan kurang lebih banyak dibandingkan dengan pengetahuan cukup dan baik. Hasil uji statistik dengan menggunakan Chi-Square untuk melihat hubungan pengetahuan dengan asupan serat makanan diperoleh nilai $p=0,002(<0,05)$ artinya ada hubungan pengetahuan dengan asupan serat makanan. Hasil ini sesuai dengan penelitian Puspita (2014) yang menyatakan terdapat hubungan pengetahuan dengan konsumsi makanan berserat. Ulfah (2011) menyatakan terdapat hubungan antara pengetahuan serat dengan konsumsi serat mahasiswa Universitas Indonesia Depok. Pengetahuan gizi menjadi landasan seseorang dalam menentukan konsumsi pangan. Ulfah (2011) menyatakan pengetahuan yang tingi mengenai serat makanan dapat membuat seseorang lebih sering mengonsumsi serat.

$\begin{array}{cccr}\text { Hal } & \text { ini tidak } & \text { sejalan } & \text { dengan } \\ \text { penelitian } & \text { Wulandari } & (2009) & \text { yang }\end{array}$
menyatakan tidak ada hubungan antara tingkat pengetahuan gizi dengan konsumsi serat.

Dari tabel 1 dapat diketahui bahwa subjek laki-laki lebih sedikit dibandingkan perempuan. Hasil uji statistik dengan menggunakan uji Chi-Square untuk melihat hubungan jenis kelamin dengan asupan serat makanan diperoleh nilai $p=0,003 \quad(<0,05)$ artinya ada hubungan antara jenis kelamin dengan asupan serat makanan. Hasil ini sesuai dengan penelitian Farida (2010) yang menyatakan terdapat hubungan yang signifikan antara jenis kelamin dengan perilaku konsumsi sayur dan buah, dimana sayur dan buah merupakan sumber serat yang mudah dijumpai dalam kehidupan seharihari. Dari hasil penelitian subjek perempuan kurang mengonsumsi serat dibandingkan laki-laki, ditandai dengan asupan serat makanan rendah. Rata-rata asupan serat perempuan 9,24 gram/hari (kategori sangat kurang). Sedangkan rata-rata asupan serat makanan laki-laki 12,36 gram/hari (kategori sangat kurang). Hasil food record yang dilakukan selama 3 hari rata-rata asupan serat makanan subjek perempuan lebih kecil dibandingkan dengan laki-laki. Wulansari (2009) menyatakan remaja lakilaki cenderung tidak menyukai makanan ringan atau makanan yang tidak mengenyangkan sehingga asupan makanan pada laki-laki cenderung tinggi. Rendahnya asupan pada perempuan juga dapat 
disebabkan karena perempuan cenderung membatasi asupan makanan.

Hal ini tidak sesuai dengan pernyataan Fibrihirzani (2012) menyatakan perempuan memiliki kecenderungan mengonsumsi buah dan sayur 3,5 kali lebih besar dibandingkan laki-laki. Hal ini dikarenakan rasa kesukaaan terhadap buah dan saur yang tinggi dibandingkan laki-laki.

Sebagian besar teman sebaya tidak berperan terhadap subjek. Hasil uji statistik dengan menggunakan Chi-Square untuk melihat hubungan peran teman sebaya dengan asupan serat makanandiperoleh nilai $p=0,001(<0,05)$ artinya ada hubungan peran teman sebaya dengan asupan serat makanan. Hal ini sejalan dengan penelitian Aryani (2016) menyatakan bahwa terdapat hubungan yang signifikan antara teman sebaya dengan perilaku konsumsi buah dan sayur. Asupan serat makanan dengan kategori tidak berperan cenderung sangat kurang (kurang dari 15 gram per hari), hal tersebut dapat dikarenakan kurangnya interaksi dengan teman padahal teman sebaya dapat mempengaruhi asupan makanan seseorang. Hal ini sesuai dengan penelitian Aryani (2016) yang menyatakan subjek dengan peran teman sebaya positif konsumsi sayur dan buah cenderung tinggi sedangkan subjek dengan peran teman negatif konsumsi sayur dan buah cenderung kurang.

Hal ini tidak sejalan dengan penelitian Ulfah (2011) yang menyatakan tidak ada hubungan pengaruh teman sebaya dengan kebiasaan konsumsi serat makanan Mahasiswa Universitas Islam Depok.

Subjek lebih banyak yang bertempat tinggal di kost dibandingkan dengan rumah sendiri. Hasil uji statistik dengan menggunakan Chi-Square untuk melihat hubungan tempat tinggal dengan asupan serat makanan diperoleh nilai $p=0,000(<0,05)$ artinya ada hubungan tempat tinggal dengan asupan serat makanan. Penelitian Jago et al (2007) menyebutkan bahwa lingkungan fisik tempat tinggal dan kemudahan akses dalam mencapai tempat penjualan makanan berhubungan dengan konsumsi seseorang. Hal ini sejalan dengan penelitian farida (2010) menyatakan bahwa tempat tinggal seseorang berhubungan dengan konsumsi sayur dan buah, karena tempat tinggal berpengaruh terhadap perilaku konsumsi seseorang, termasuk dalam hal ketersediaan pangan pada daerah tersebut. Sutiah (2009) menyatakan terdapat hubungan yang signifikan antara tempat tinggal dengan perilaku konsumsi buah dan sayur.

Sebagian subjek bertempat tinggal di kost karena sebagian besar berasal dari luar kota (Jember). Rata-rata asupan serat makanan yang bertempat tinggal di kost 9,5 gram/hari, hal ini termasuk dalam kategori sangat kurang (kurang dari 15 gram/per hari). Sedangkan rata-rata asupan serat subjek yang bertempat tinggal di rumah sendiri 12,4 gram/hari, hal ini termasuk dalam kategori sangat kurang (kurang dari 15 gram/per hari). Sumber serat terbanyak yang dikonsumsi subjek yang bertempat tinggal di kost maupun rumah sendiri ialah sayur, akan tetapi hanya jumlah sayur yang dikonsumsi berbeda. Rata-rata konsumsi sayur subjek kost adalah 70 gram/hari, sedangkan subjek yang bertempat tinggal di rumah sendiri/rumah saudara 98 gram/hari. Ratarata konsumsi buah subjek yang bertempat tinggal di kost 30 gram perhari, sedangkan subjek yang bertempat tinggal di rumah sendiri 40 gram/hari. Farisa (2012) menyatakan ketersediaan buah dan sayur di rumah berhubungan dengan perilaku konsumsi buah dan sayur pada remaja. Menurut reynolds et.al (2007) jenis makanan sayur dan buah yang tersedia di rumah lebih banyak mempunyak peluang yang lebih besar untuk dikonsumsi, sedangkan jenis makanan yang tidak tersedia tidak akan dikonsumsi seseorang.

\section{Simpulan dan Saran \\ 4.1 Simpulan}

Berdasarkan hasil penelitian didapatkan kesimpulan:

a. Ada hubungan jenis kelamin dengan asupan serat makanan Mahasiswa Politeknik Negeri Jember dengan nilai $0,003(\rho>\alpha 0,05)$.

b. Ada hubungan pengetahuan mengenai serat makanan dengan asupan serat Mahasiswa Politeknik Negeri Jember $0,002(\rho>\alpha 0,05)$.

c. Ada hubungan peran teman sebaya dengan asupan serat makanan 
Mahasiswa Politeknik Negeri Jember $0,001(\rho>\alpha 0,05)$.

d. Ada hubungan tempat tinggal dengan asupan serat makanan Mahasiswa Politeknik Negeri Jember 0,000 $(\rho>\alpha$ $0,05)$.

\subsection{Saran}

a. Melakukan penelitian lebih mendalam mengenai asupan serat, seperti mengenai hubungan media sosial dengan asupan serat.

b. Menggunakan instrumenn wawancara terstruktur dalam menggali variabel tempat tinggal

\section{Daftar Pustaka}

Santoso, A. (2011). Serat Pangan (Dietary Fiber) dan Manfaatnya bagi Kesehatan. Magistra. No.75. Hlm. 35-40.

Sunarti. (2017). Serat Pangan dalam Penanganan Sindrom Metabolik. Yogyakarta: Gadjah Mada University Press.

Kementerian Kesehatan Republik Indonesia. (2013). Riset Kesehatan Dasar Tahun 2013. Jakarta: Badan Penelitian dan Pengembangan Kesehatan Kementerian Kesehatan Republik Indonesia.

Notoatmodjo, S. (2007). Kesehatan Masyarakat Ilmu dan Seni. Jakarta: Rineka Cipta

Soetjiningsih. (2010). Buku Ajar Tumbuh Kembang Remaja dan Permasalahannya. Jakarta: CV Sagung Seto

Khomsan. (2010). Pangan dan Gizi untuk Kesehatan. Jakarta: Raja Grafindo Persada

Suhardjo, dkk. (2007). Pangan, Gizi dan Pertanian. Jakarta: Universitas Indonesia Press

Kementerian Kesehatan Republik Indonesia. (2014). Pedoman Gizi Seimbang.
Jakarta: Kementerian Kesehatan Republik Indonesia

Puspita, D. S. (2014). Perilaku Konsumsi Makanan Berserat Karyawan PT. Pertamina (Persero) Unit Pengolahan IV Cilacap. Yogyakarta: Universitas Negeri Yogyakarta.

Ulfah, N. (2011). Hubungan antara Karakteristik Individu dan Pengaruh Teman Sebaya dengan Kebiasaan Konsumsi Serat Makanan pada Mahasiswa Penghuni Asrama Universitas Indonesia Depok. Skripsi: Universitas Indonesia.

Wulandari, P. (2009). Hubungan Tingkat Pengetahuan Gizi dengan Konsumsi Serat pada Remaja SMA Muhammadiyah 1 Klaten. Karya Tulis Ilmiah. Surakarta.

Universitas Muhammadiyah Surakarta.

Farida, I. (2010). Faktor-Faktor yang Berhubunngan dengan Perilaku Konsumsi Buah dan Sayur pada Remaja di Indonesia Tahun 2007. Skripsi. Universitas Islam Negeri Jakarta

Wulansari, N. D. (2009). Konsumsi Serta Prefensi Buah dan Sayur pada Remaja SMA dengan Status Sosial Ekonomi yang berbeda di Bogor. Skripsi. Bogor. Institut Pertanian Bogor

Fibrihirzani, H. (2012). Hubungan Sikap, Pengetahuan, Ketersediaan dan Keterpaparan Media Massa dengan Konsumsi Sayur dan Buah pada Siswa SMPN 8 Depok tahun 2012. Skripsi. Depok

Aryani, D. D. (2016). Hubungan Peran Teman Sebaya dengan Perilaku Konsumsi Buah dan Sayur pada Remaja Awal di SMP Negeri 1 Nglipar Gunung Kidul Yogyakarta. Skripsi. Stikes Jenderal Ahmad Yani Yogyakarta 
Jago, R., Tom, B., Janice, C.B., Karen, W.C., Debbe, T. (2007). Distanceti Food Stores \& Adolescent Male Fruit and Vegetable Consumption: Mediation Effect. International Journal of Behavioral Nutrition And Physicalactivity. Act; 4:35

Sutiah, E. (2009). Analisis Hubungan Pengetahuan Gizi, Motivasi, Persepsi dan Sikap dengan Kebiasaan Makan Sayuran Ibu Rumah Tangga Perkotaan dan Pedesaan di Bogor. Skripsi. Bogor

Farisa, S. (2012). Hubungan Sikap, Pengetahuan, Ketersediaan dan Keterpaparan Media Massa dengan Konsumsi Buah dan Sayur pada Siswa SMPN 8 Depok tahun 2012. Skripsi. Universitas Indonesia.

Reynolds, K et.al. (2007). Patterns in Child And Adolescent Consumption of Fruit and Vegetables: Effect of Gender and Ethnicity Across Four Sites. Journal Of the American College of Nutrition. Vo. 18, No.3,248-254 